Volume 9, No.3, May - June 2020

International Journal of Advanced Trends in Computer Science and Engineering

Available Online at http://www.warse.org/IJATCSE/static/pdf/file/ijatcse168932020.pdf

https://doi.org/10.30534/ijatcse/2020/168932020

\title{
Water-Flow-Like Algorithm based Decision Support Model for Flood Control Operation System
}

\author{
Rachmat $^{1}$, Ditdit Nugeraha Utama ${ }^{2}$ \\ Computer Science Department, BINUS Graduate Program-Master of Computer Science, \\ Bina Nusantara University, Jakarta, Indonesia 11480 \\ ${ }^{1}$ rachmat@binus.ac.id \\ 22ditdit.utama@binus.edu
}

\begin{abstract}
Prediction of water level functioned by the local government Jakarta has only been tidal forecasts or predictions of water levels at sea. At present there is no open and close floodgate regulation system either through mathematical calculations or decision-making models that produce accurate numbers. The purpose of this research is to find out what parameters are involved in determining the floodgate opening using the water flow algorithm (WFA) method. It operated to model the river water flow to get the best decision for opening and closing floodgate in flood control of Manggarai floodgate in Jakarta. This research used quantitative data analysis method. The data reported was real data coming from the field. At the end of this study, the relationship between water level reported every hour and the amount of time needed for the water reservoir at the Manggarai floodgate to be fully alerted has been determined. WFA implemented academically in this study was functioned to predict the flow of water at the Manggarai floodgate, as a result of the flow of water coming from the Katulampa weir. Based on the prediction results of the water discharge, we are able to get the volume of water from the Manggarai floodgate, thus we are able to determine open decisions close at the Manggarai floodgate.
\end{abstract}

Key words: Water level, water flow, water velocity, flood, decision support model, water flow algorithm.

\section{INTRODUCTION}

DKI Jakarta was firstly named Sunda Kelapa. Until now, it has been a "customer's flooding" during the rainy season, recorded starting from 1699 until now [1]. Flood infrastructure development and its conservation efforts were constructed only to reduce the potential risk of flooding. They are not able to eliminate the flood itself perfectly [2]. This is because the capacity of the flood control system in Jakarta is only able to serve the flood load from the local drainage system [3]. Because the water level update model is carried out in each measuring station [4], this has the potential for writing errors.
Flooding has become a serious threat to urban areas and coastal areas, over time, with climate change causing sea level rise and extreme rainfall that is sometimes difficult to predict, land subsidence caused by the construction of high rise buildings and lifestyle changes. In terms of socioeconomic make the area affected by flooding will be more extensive each year. [5] explained that the characteristics of Jakarta in terms of content regarding the technical steps to deal with flooding is still an appeal not a clear practical step. The spatial management model projected in 2030 is going to have a very important role in managing floods by developing a more integrated form of flood risk management. Based on the research analysis [6], the main causes of flooding are the disposal of plastic waste, household waste or indiscriminate industrial waste, the reduction of rainwater recipe areas due to urbanization and deforestation as well as the lack of carrying capacity regarding flood management infrastructure. Other causes of flooding are reduced width of river waterways or rivers that cross residential areas, office buildings, malls or factories.

[7] mentioned potential flooding areas occur in slums that are still around riverbanks or rivers that are not intended as residential areas. A number of solutions have been carried out by the local government by developing drainage systems, flood defenses and embankments along river banks. To reduce the risk of research flooding problems, [8] developed a risk model that is able to produce flood damage estimates in the same order as when flood events were reported. Flood risk mapping can be used as a tool to increase awareness about flooding in the community, in addition it can improve community relations with the authorities in discussing and designing preventive measures that may occur during a flood.

Water flow algorithm (WFA) which is one of the heuristic optimization methods has been widely used to solve various complex problems that have occurred for decades [9]. The natural behavior of water flowing from higher to lower places, has been widely used in designing algorithmic models as applied in research [10]. The modeling of river water flow was built based on the method WFA. It was useful for opening 
and closing the floodgate system to eliminate the flood. It was expected to provide an optimal decision proposal for the open and close model of the floodgate with the aim to reduce the overflow of water that can cause flooding.

In terms of real time data as is the case [11], this model will present a predictive data model by utilizing river water level monitoring in real-time. The WFA implemented in this study is also operated to scientifically envisage the flow of water at the Manggarai floodgate, as a result of the flow of water coming from the Katulampa weir, from the prediction results of the water discharge we will get the volume of water from the Manggarai floodgate so that we can determine open decisions close at the Manggarai floodgate.

\section{RELATED WORK}

Numerous researchers used the WFA method as the main method in their research. WFA was first developed by [10] to solve the problem of optimizing the grouping of objects known as bin-packing problems (BPP). In practice, this BPP problem needs heuristic modeling so that the resulting solution can be more optimal and feasible to be implemented. The movement of water flow which is influenced by the force of gravity and the law of conservation of energy, flows with a repetition model that moves from the highlands to the lowlands. [10] explained and mapped how water flows by splitting, moving and dynamically rejoining behavior in each iteration. In the iteration concept of the WFA model, the process is similar to what was explained in the study [12], by optimizing the process with the full factorial method, where there is a repetition in finding the best value of the objective function by scanning all parameter values. The processes above will go through the calculation process of the formula calculation which contains numeric and variable values as explained by [13] about optimizing numerical calculations and variables in the decision making model.

Several studies that have been developed in relation to flood prediction, for example, use the decision support management of floods (DESMOF) model which was one of the models used to predict floods and create flood control functions in the Manitoba Red River, Canada [14]. The WFA model is one of the heuristic optimization methods which is inspired by the natural behavior of the water flow [15]. The most optimal determination of vehicle routes related to the process of distribution of goods from selling agents to customers has also been implemented using the WFA model [16].WFA has also been applied to determine the shortest route in the sales process carried out by a salesman traveling around, visiting each city with the shortest route and returning to the city of origin in a timely manner [17].
Expert system becomes one of the models used to be a tool in making a decision where the expert system design concept related to flood early warning [18]. Whereas for some studies with expert systems, ultrasonic sensors [19] used as part of this expert system method [20] with ultrasonic sensors the input water level data can be directly sent to the data center available [21]. The application of the WFA model to other sectors can be found in the grouping of factory machines which can produce several decisions about efficiency, the model of the grouping of factory machines is used to produce maximum performance [22] [23]. Recent research in [24] was a prediction model that develops artificial neural networks to predict daily water levels in a river, using the whale optimization neural network (WONN) method, the method was a combination of two algorithms namely the whale optimization algorithm and neural network optimization

\section{RESEARCH METHODOLOGY}

This study proposed the WFA as the main method for model construction [17]. WFA method has four main operations namely separation and flow movement, flow integration, water evaporation, and rainfall. Object-oriented method [25] was also functioned to design and model.

Retrieval and testing using empirical data were conducted at the Manggarai floodgate, precisely before the inflow of water from the Katulampa direction to the Manggarai floodgate. Empirical data retrieval was done by a paper boat that is run at three different locations, this test was carried out to get the initial average speed of water while still referring to the concept of water flowing from the highlands to the lowlands. Sub-streams will later become one when they meet in the same location [26]. The total field test data were carried out 14 times using a test range with a range of $30 \mathrm{~m}$ to $75 \mathrm{~m}$, the time taken from the test was obtained with a range of time from 33 s to 100 s, for the water level at that time in the range of $5.2 \mathrm{~m}$ to $6 \mathrm{~m}$ which means that it is at 4 or normal status. Broadly speaking, the stages of this research are explained in Figure 1.

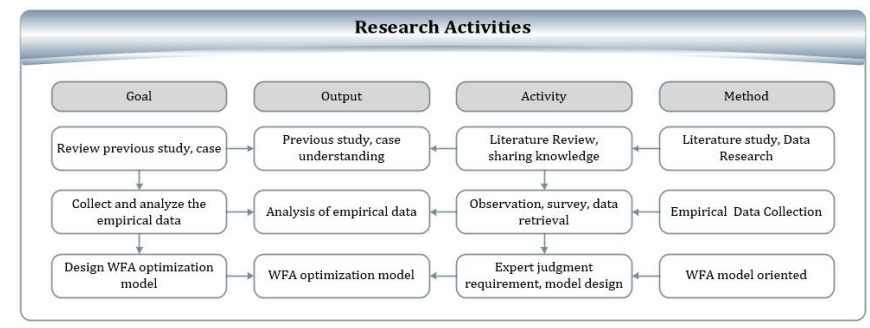

Figure 1: Research Activities

Modeling diagram used in this study was activity diagrams that illustrate business processes and the sequence of activities in the system being built, while for defining parameters using a parameter operating diagram, to make it 
more clear what parameters are involved in this model. The term formula in hydraulics is also explained using three-dimensional drawings with the Sketchup program, finally for the sketch of the flow the flow of water from the Katulampa weir to the Manggarai floodgate is explained.

The data base was determined from empirical data from the field test results. The determination of the value in the database was used by using a basic assumption that was with a value of $1 \mathrm{~m}$ distance, $1 \mathrm{~s}$ travel time, water velocity $1 \mathrm{~m} . \mathrm{s}^{-1}$, river width $1 \mathrm{~m}$, water level $1 \mathrm{~m}$, with the value of the density of water density of $1,000 \mathrm{~kg} \cdot \mathrm{m}^{-3}$, so that the volume of water obtained by $1 \mathrm{~m}^{3}$ and base momentum of $1,000 \mathrm{~kg} \cdot \mathrm{m} . \mathrm{s}^{-1}$. Based on the results of calculation of the database and the analogy, the value of the water velocity coefficient obtained. It was coming from the average speed value divided by the average value of the water level. The water velocity coefficient of $3.92 \mathrm{~m} . \mathrm{s}^{-1}$ was obtained and the water level coefficient of $0.72 \mathrm{~m}$. The gravity value of the earth is assumed to be $9.807 \mathrm{~m} . \mathrm{s}^{-2}$, while the distance of water flow from Katulampa to Manggarai is $110 \mathrm{~km}$.

The formulas related to hydraulic calculations were also functioned to calculate water velocity and water discharge data after empirical data collection is done in the field, where the required data is $h$ water level data, the deep river $b$ in Katulampa has a constant value of $65 \mathrm{~m}$, whereas for width the river in Manggarai has a constant value of $30 \mathrm{~m}$. The coefficient value under the channel is denoted by $n$, taken based on the channel coefficient of natural channel type flood plain lot of disturbing plants [26]. The slope of the channel bottom is denoted by $S$ (4) which is derived from equation (3) by units per mile.

Perimeter of water is calculated by equation (1); where $b$ is the width of the river, $h$ is the water level and $\mathrm{m}$ is the unit slope of the channel with a constant value of 0.05 . The cross-sectional area of the river symbolized by $A$ is calculated based on the width of the river $b$ multiplied by the water level $h(2), v$ is velocity of water, it is formulated by equation (3), where $R$ is the hydraulic radius and $S$ represent the base slope of the $S$ channel. Whereas the derivative of the $S$ channel's slope formula can be shown in equation (4). For water discharge is denoted by $Q$ taken from the multiplication between cross-sectional area and water velocity (5). The formula in equation (5) uses the supporting variables found in table 1 .

$$
\begin{aligned}
& b+2 h \\
& b \times h \\
& \frac{1}{n} \times R \frac{2}{3} \times S \frac{1}{2}
\end{aligned}
$$

$$
\begin{aligned}
& S=\left(\frac{n \times V}{R \frac{2}{3}}\right) \\
& \mathrm{Q}=\mathrm{A} \times \mathrm{V}
\end{aligned}
$$

\begin{tabular}{|c|c|c|c|}
\hline Symbol & Description & Value & Unit \\
\hline$h$ & Water level & Data & $\mathrm{m}$ \\
\hline$b$ & Upper River Width & 20 & $\mathrm{~m}$ \\
\hline$m$ & Slope of the channel & 0.05 & constant \\
\hline$n$ & $\begin{array}{l}\text { Manning Coefficient, } \\
\text { basic coefficient of } \\
\text { channel Type Natural } \\
\text { Channel Flood Plain } \\
\text { Many Disturbing } \\
\text { Plants [27] }\end{array}$ & 0.05 & constant \\
\hline$S$ & 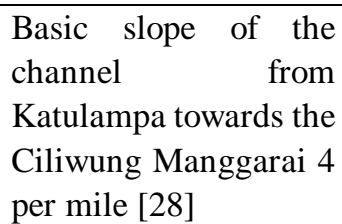 & 0.004 & constant \\
\hline$S$ & $\begin{array}{l}\text { The Basic Slope of the } \\
\text { Channel Along the } \\
\text { Ciliwung Manggarai } \\
\text { River 0,2 per mile [28] }\end{array}$ & 0.0002 & constant \\
\hline$P$ & $\begin{array}{l}\text { The Perimeter water in } \\
\text { the cross section of the } \\
\text { river }\end{array}$ & $b+2 h$ & $\mathrm{~m}$ \\
\hline A & $\begin{array}{l}\text { River cross-sectional } \\
\text { area }\end{array}$ & $b \times h$ & $\mathrm{~m}^{2}$ \\
\hline$R$ & Hydraulic radius & $A / P$ & \\
\hline$v$ & Water Velocity & $\frac{1}{n} \times R \frac{2}{3} \times S \frac{1}{2}$ & $\mathrm{~m} \cdot \mathrm{s}^{-1}$ \\
\hline$Q$ & Water discharge & $\mathrm{A} \times \mathrm{V}$ & $\mathrm{m} \cdot \mathrm{s}^{-1}$ \\
\hline
\end{tabular}

Table 1: Hydraulic calculation formula

\section{RESULT AND DISCUSSION}

This study used water flow data that extended from the Katulampa weir to the Manggarai floodgate, because by the form of the flow scheme from the Katulampa weir to the Manggarai floodgate shown in Figure 2. The parameters associated with the decision to open and close the floodgate were documented through a parameter diagram, as shown in Figure 4. In this picture clearly the parameters used and those involved in modeling the system, with a three-dimensional drawing of hydraulic calculations and parameters used, involve are shown in Figure 3. Table 2 explains the definition of the WFA parameter analogy used when the model is implemented into this research, changes in the analogy parameters are seen in the determination of the symbol speed, flow mass and flow momentum. 


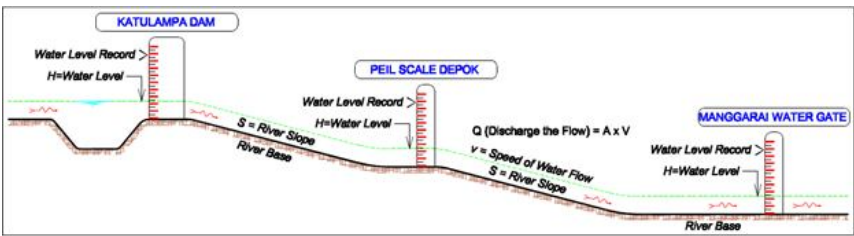

Figure 2: Sketch of water flow from Katulampa weir to Manggarai Floodgate

Table 2: WFA and real analogy parameters

\begin{tabular}{|c|l|c|c|}
\hline No & \multicolumn{1}{|c|}{ Description } & WFA & Real \\
\hline 1 & Number of sub flow $\boldsymbol{i}$ & $n i$ & $f_{i}$ \\
\hline 2 & $\begin{array}{l}\text { The number of } \\
\text { sub-flows that can split } \\
\text { from a flow }\end{array}$ & $\bar{n}$ & $\bar{f}$ \\
\hline 3 & Velocity & $V_{\text {soulution }}$ & $V_{\text {prediction }}$ \\
\hline 4 & Mass flow & $W_{i k}$ & $M_{i k}$ \\
\hline 5 & Momentum flow & $\mu_{i}$ & $P_{i}$ \\
\hline 6 & $\begin{array}{l}\text { Flow height alignment } \\
\text { characteristics }\end{array}$ & $\delta_{i}$ & $d_{i}$ \\
\hline 7 & Flow iteration & $k$ & $k$ \\
\hline 8 & $\begin{array}{l}\text { Gravitational } \\
\text { acceleration }\end{array}$ & $g$ & $g$ \\
\hline 9 & Base Momentum & $T$ & $T$ \\
\hline
\end{tabular}

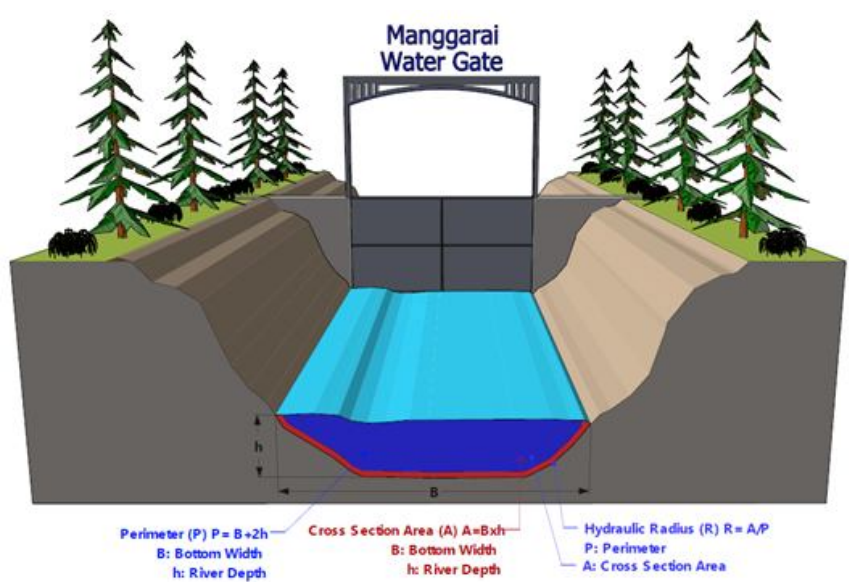

Figure 3: Hydraulic parameters

Based on Figure 4, there are three independent parameters (i.e. water level, mane efficiency and slope channel). These three parameters determine the final result of the water velocity that occurs. The calculation of the water discharge parameter depends on the previous parameter, being the single parameter that will be the determining variable in finding the level of water that should be. For a description of the process and sequence of activities in the model built, shown in Figure 5.

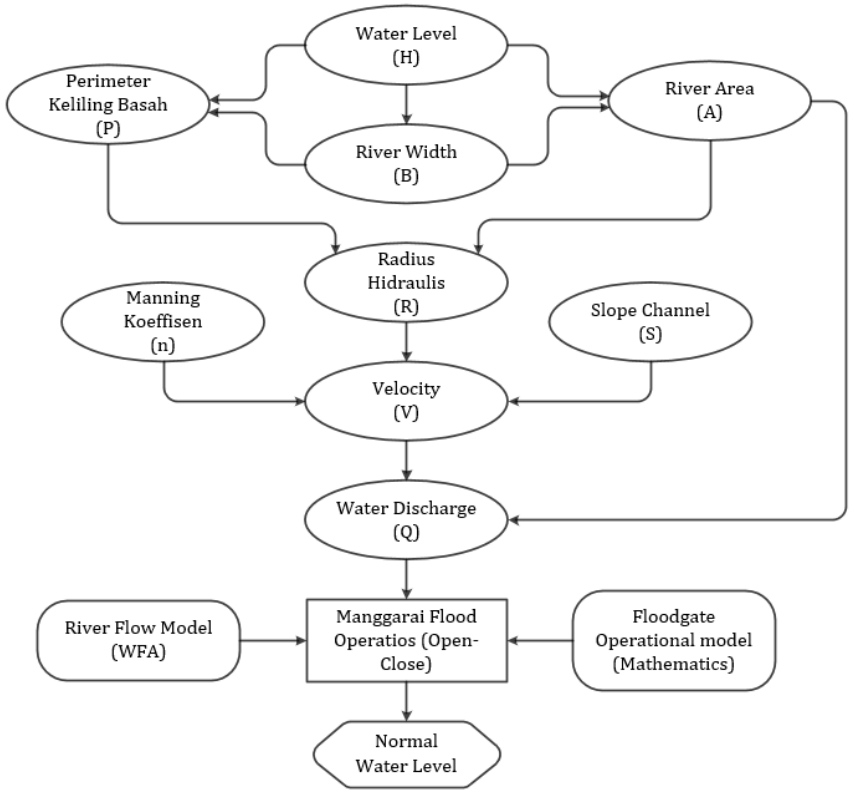

Figure 4: Operated Parameter

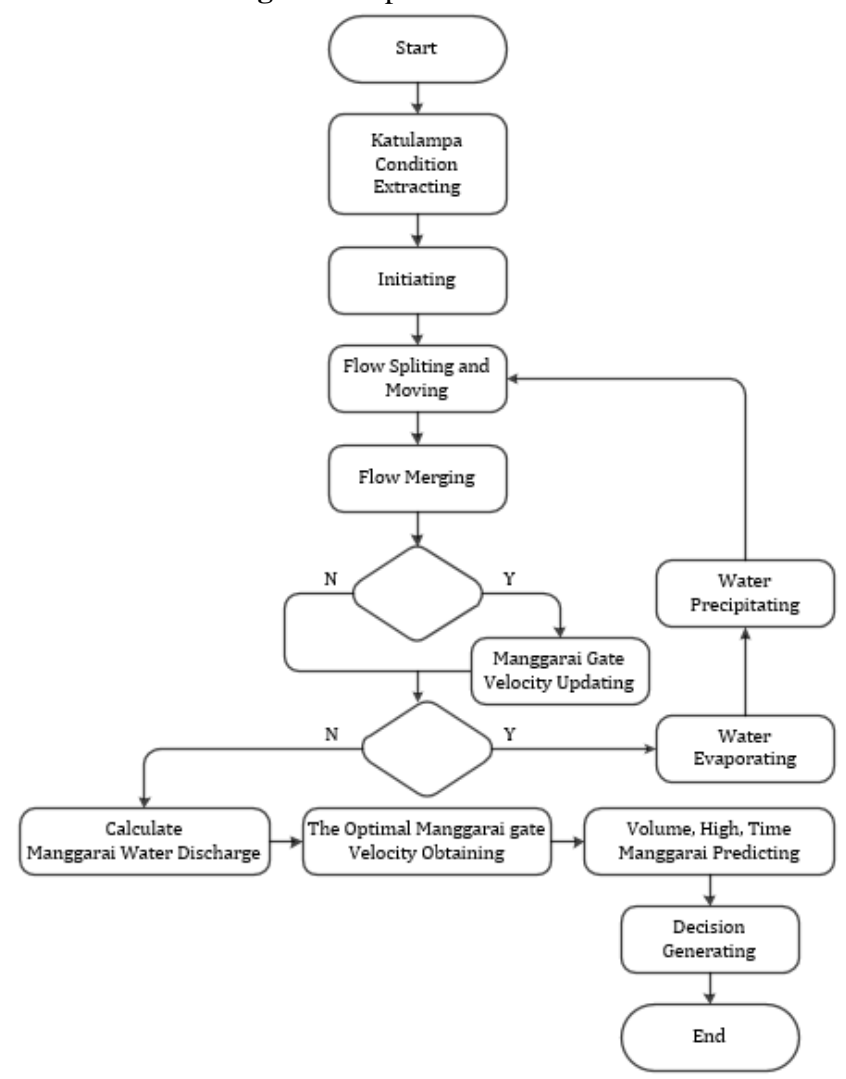

Figure 5: Activity Diagram

The process that occurs begins with the reading of the upstream water level data in this case is the water level at the Katulampa weir, the acceleration parameters are also considered in this activity such as rain, so not only water coming from the Katulampa weir, in addition to acceleration is also considered slowing speed for example if there is evaporation due to solar heat so that the speed is reduced because the water discharge is also reduced due to evaporation. 
From the results of the field test the initial value of the distance was determined to be $30 \mathrm{~m}$, with a test time of $10 \mathrm{~s}$, from the data before knowing the water level coefficient of $0.71 \mathrm{~m}$, then with a speed coefficient of 3.92 the water velocity was 7.83 , the volume of water was $1,800 \mathrm{~m}^{3}$ and the mass type of water $1,800,000 \mathrm{~kg}$. The formulas related to the water flow algorithm are divided based on the maximum and minimum values (6) and the obtained velocity values (7) [15]; where $f_{i}$

is the number of sub-streams identified based on the current water velocity $\left(v_{i}\right) \cdot \bar{f}$ is the boundary symbol of the sub-stream separated from one stream (in this study 3 streams have been determined). $W_{i} V_{i}$ is the momentum from flow to $i$ and $T$ is the basic momentum.

$$
\begin{gathered}
f_{i}=\min \left\{\max \left\{1, \operatorname{int}\left(\frac{M_{i} V_{i}}{T}\right)\right\}, \bar{f}\right\} \\
V_{\text {prediction }}=\frac{M_{i} P_{i}+M_{k} P_{k}}{M_{i}+M_{k}} \\
M_{i k}=\left(\frac{n_{i}+1-k}{\sum_{r}^{n_{i}} r}\right) M_{i} ; k=1,2,3, \ldots, f_{i} \\
P_{i k}=\left\{\sqrt{V_{i}^{2}+2 g d_{i k}}, i_{f} V_{i}^{2}+2 g d_{i k}>0\right\} \\
d_{i k}=\left\{\begin{array}{l}
f\left(X_{i}\right)_{-} f\left(y_{i k}\right), \text { for minimize } \\
f\left(U_{i k}\right)-f\left(X_{i}\right), \text { for maximize }
\end{array}\right.
\end{gathered}
$$

When flow $i$ is divided into $n_{i}$ sub-flows, the mass of each sub-stream $\left(M_{i k}\right)$ is recalculated using equation (8), where $k=1,2,3, \ldots, f_{i}$. The sub-flow velocity $k$ divided from flow $i$ $\left(P_{i k}\right)$ is calculated using the energy conservation equation in equation (9); where $g$ the acceleration due to gravity and $d_{i k}$ is the characterization of the elevation of the height of each flow $i$ sub-stream $k$, it can be measured using equation (10). Thus, the water velocity can be measured through equation (7) based on the concept of flow incorporation.

Based on empirical data and a predetermined database, the formula (6) WFA was used. From the results of calculations using equation (6), the number of sub-streams obtained with the value $\bar{f}$ maximal 3. Based on formula (8) WFA obtained the mass of each flow, with the last nth flow of $3, r$ is the cumulative value of $k$. The first, second and third mass flow respectively obtained from equation (6) is $5,400,000 \mathrm{~kg}$, $1,200,000 \mathrm{~kg}$, and $300,000 \mathrm{~kg}$.

Furthermore, the momentum value of each flow will be calculated using the formula (9) WFA, $d_{i k}$ is the characterization of the decrease in height value of the $k$-flow, the value taken from table 1 is 0.0075 . The base slope of the $1^{\text {st }}$ to $3^{\text {rd }}$ flow is in the range 0.004 to 0.012 , so by using the equation formula (9) the momentum values of the first, second and third flows are respectively $7.84 \mathrm{~kg} . \mathrm{m} . \mathrm{s}^{-1}$, $7.85 \mathrm{~kg} \cdot \mathrm{m} \cdot \mathrm{s}^{-1}$, and $7.86 \mathrm{~kg} \cdot \mathrm{m} \cdot \mathrm{s}^{-1}$.

The last calculation operation of the flow movement model is to find the value of $V_{\text {prediction }}$ using equation (2). The predictive value of $v$ is the number of multiplications of mass and momentum for the entire flow, obtained from equation (2) of $7.84 \mathrm{~km} / \mathrm{h}$. The distance from Katulampa to the Manggarai floodgate is $110 \mathrm{~km}$, so the water travel time to the Manggarai floodgate is $3.90 \mathrm{~h}$.

In the natural behaviours of water, there is a process of evaporation in which water evaporated into the atmosphere which is then deposited by clouds and at a certain temperature will be shed again in the form of rain drops. Likewise with WFA that uses the natural concept of water, the evaporation process will occur after the water moves from one location to another. The evaporation process in WFA can be presented in the same form (11).

$M_{i}=\left(1-\frac{1}{t}\right) M_{i} ; i=1,2,3, \ldots, n$

Where $t$ is the time specified in the next hour, mass $M_{i}$ is taken from the average flow result. From the results of the previous description, if the calculated speed is considered as the $1^{\text {st }}$ time arrived, then when there is evaporation the $2^{\text {nd }}$ travel time is used, using equation (11), the total mass of water obtained after the evaporation process is 900,000 . By using equation (7), the water velocity value after the evaporation process is $14.12 \mathrm{~km} \cdot \mathrm{h}^{-1}$, so the distance of water from Katulampa to the Manggarai water gate under the condition of water evaporation is $7.79 \mathrm{~h}$ slower than $3.90 \mathrm{~h}$ of normal calculation results.

As with evaporation, precipitating can also affect the results of the calculated solution speed, the type of acceleration that exists in WFA, one of which is rainfall, which with the addition of water discharge due to rain will accelerate the flow of water that moves from one location to another. Water acceleration in WFA is presented in equation (12).

$M_{i}^{\prime}=\left(\frac{M_{i}}{\sum_{k=1}^{N} M_{k}}\right) M_{0} ; i=1,2,3, \ldots, n$

Where $\mathrm{W}_{0}$ is the mass of water at the beginning of the empirical data calculation. As with evaporation, $w_{i}$ at acceleration, travel time after the previous time has been calculated. Using equation (12), we obtain the amount of water mass after the precipitating process of 900,000. Using equation (7), the water velocity value after the precipitating process is $69.20 \mathrm{~km} \cdot \mathrm{h}^{-1}$. Thus the distance of water from Katulampa to the Manggarai floodgate with the condition that the acceleration of the water becomes faster $1.59 \mathrm{~h}$ from $3.90 \mathrm{~h}$ normal time calculation. 
Figure 6 shows the prediction data of the arrival time of water, when water flows from the Katulampa weir to the Manggarai floodgate. Examples of such graphs are made using assumptions when the Katulampa weir time position is 09:00am. Other assumption used are the width of the Ciliwung river in Katulampa $65 \mathrm{~m}$ and the width of the Ciliwung river in Manggarai $30 \mathrm{~m}$, the results of the calculations in Figure 6 consider the acceleration parameters caused by rain.

Calculation of water volume uses the cube formula for each flow of water that flows in the Ciliwung rivers from the Katulampa weir to the Manggarai floodgate. When the water warning status in Katulampa is on alert 1, the water that comes out of the Katulampa weir to the Manggarai water gate takes $6.9 \mathrm{~h}$ so that the water will reach the Manggarai water gate at $03: 54 \mathrm{pm}$.

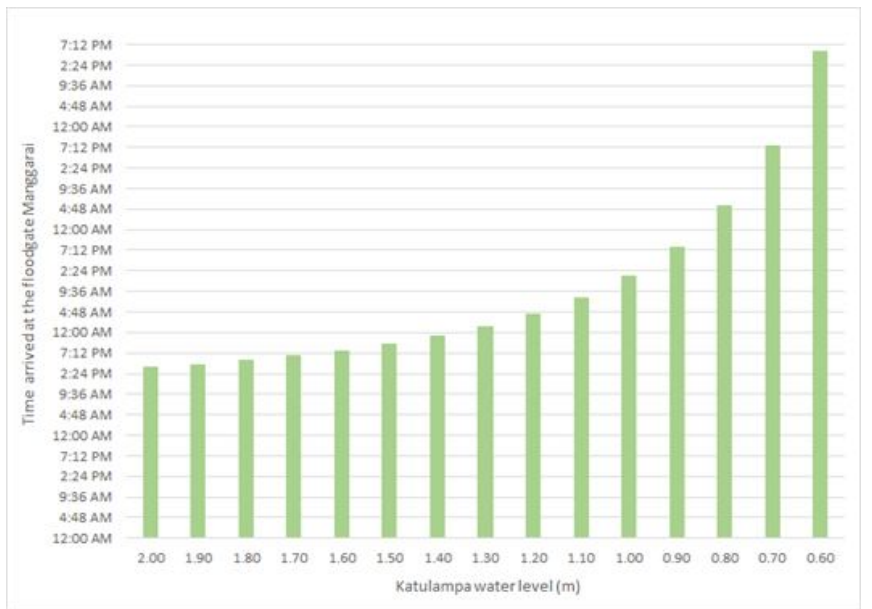

Figure 6: Time arrived at the Manggarai floodgate

Figure 7 shows a graphical report that aims to find out the amount of volume of water reaching the Manggarai floodgate. Assumption data from the grader is made when the warning status is Katulampa at standby 1 , in this case $2 \mathrm{~m}$. Graph also used the assumption width of the river of Ciliwung in Katulampa $65 \mathrm{~m}$ and the width of the river Ciliwung in Manggarai $30 \mathrm{~m}$. Like Figure 6, the calculation of water volume also uses a cube formula for each flow of water that flows in the Ciliwung rivers from the Katulampa weir to the Manggarai floodgate.

From this condition, Manggarai sluice opening is simulated by adding openings every $0.1 \mathrm{~m}$. The $0.2 \mathrm{~m}$ value is the default status of the Manggarai floodgate which is used as the initial opening of the floodgate. The maximum height of the Manggarai sluice opening that can be done is $2 \mathrm{~m}$, in Figure 7 the higher the sluice opening, the height of the water at the Manggarai sluice is getting lower.

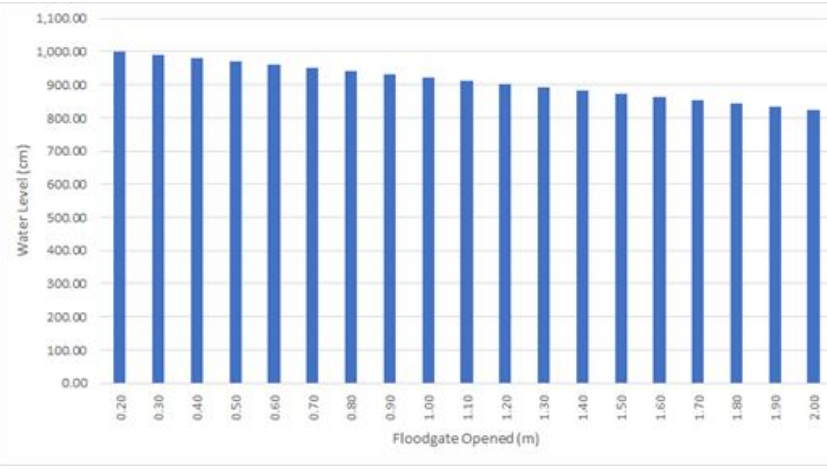

Figure 7: Manggarai floodgate opened

\section{CONCLUSION}

From the results of empirical data testing in the field, this WFA model was successfully implemented in the Manggarai floodgate operations and managed to get the best solution speed. The speed of the solution when the normal water level is $7.84 \mathrm{~m}$, obtained the travel time of water from Katulampa to the Manggarai floodgate for $3.90 \mathrm{~h}$, and in this study also identified the parameters involved, first, evaporation, where with normal water level if there is evaporation then the time required to be slower $7.79 \mathrm{~h}$. Secondly the acceleration, where with normal water level, if there is an acceleration, the time taken will be $1.59 \mathrm{~h}$ faster.

In further research developments it may be possible to add other parameters in the calculation using this WFA, for example the presence of garbage along the banks of the river which makes the process of slowing down the water velocity to be greater. It can also be done by using other methods that can be used as a comparison for example early warning methods and flood prediction based on the similarity theory [29], or even still using WFA but combined with the concept of fuzzy logic, the development of fuzzy logic models can use models that are commonly used [30], or fuzzy logic that is specific as needed [31].

\section{ACKNOWLEDGEMENT}

We thank Bina Nusantara University for providing sponsorship support in this research. We also thank the lecturer who gave us the opportunity and direction to complete this research in order to complete the study of Bina Nusantara Graduate Program, Master of Computer Science. Hopefully this research can be utilized and useful for many people.

\section{REFERENCES}

[1] S. Ginting and W. M. Putuhena, "Sistem Peringatan Dini Banjir Jakarta (Jakarta-Flood Early Warning System (J-Fews)),' J. Sumber Daya Air, vol. 10, no. 1, pp. 71-84, 2014.

[2] B. Harsoyo, "Mengulas Penyebab Banjir Di 
Wilayah Dki Jakarta," J. Sains Teknol. Modif. Cuaca, vol. 14, no. 1, pp. 37-43, 2013. https://doi.org/10.29122/jstmc.v14i1.2680

[3] M. Kusuma, D. Tjahjadi, B. Bagus, and F. Farid, "Kajian Sistim Pengendalian Banjir Wilayah Tengah DKI-Jakarta Terhadap Beban Hidrograf Banjir Akibat Hujan Merata,” J. Tek. Sipil ITB, vol. 14, no. 1, pp. 41-58, 2007.

[4] X. L. Wu, X. H. Xiang, L. Li, and C. H. Wang, "Water level updating model for flow calculation of river networks," Water Sci. Eng., vol. 7, no. 1, pp. 60-69, 2014.

[5] P. J. Ward, W. P. Pauw, M. W. van Buuren, and M. A. Marfai, "Governance of flood risk management in a time of climate change: The cases of Jakarta and Rotterdam," Env. Polit., vol. 22, no. 3, pp. 518-536, 2013. https://doi.org/10.1080/09644016.2012.683155

[6] F. Steinberg, "Jakarta: Environmental problems and sustainability," Habitat Int., vol. 31, no. 3-4, pp. 354-365, 2007.

[7] M. A. Marfai, A. B. Sekaranom, and P. Ward, "Community responses and adaptation strategies toward flood hazard in Jakarta, Indonesia," Nat. Hazards, vol. 75, no. 2, pp. 1127-1144, 2015.

https://doi.org/10.1007/s11069-014-1365-3

[8] Y. Budiyono, J. Aerts, J. J. Brinkman, M. A. Marfai, and P. Ward, "Flood risk assessment for delta mega-cities: a case study of Jakarta," Nat. Hazards, vol. 75, no. 1, pp. 389-413, 2015.

[9] M. Zandieh and A. Chensebli, "Reverse logistics network design: a water flow-like algorithm approach," Opsearch, vol. 53, no. 4, pp. 667-692, 2016.

https://doi.org/10.1007/s12597-016-0250-0

[10] F. C. Yang and Y. P. Wang, "Water flow-like algorithm for object grouping problems," $J$. Chinese Inst. Ind. Eng., vol. 24, no. 6, pp. 475-488, 2007.

[11] A. Kato, R. Sinde, and S. Kaijage, "Design of an Automated River Water Level Monitoring System by using Global System for Mobile Communications," Int. J. Comput. Sci. Syst. Anal., vol. 13, no. 11, pp. 106-111, 2015.

[12] D. N. Utama, "The Optimization of the 3-d Structure of Plants , Using Functional-Structural Plant Models . Case Study of Rice ( Oryza sativa L .) in Indonesia," 2015.

[13] M. J. Druzdzel and R. R. Flynn, "Decision support systems," Underst. Inf. Retr. Syst. Manag. Types, Stand., pp. 461-472, 2011.

[14] S. Ahmad and S. P. Simonovic, "An intelligent decision support system for management of floods," Water Resour. Manag., vol. 20, no. 3, pp. 391-410, 2006.

https://doi.org/10.1007/s11269-006-0326-3

[15] D. N. Utama, F. A. Zaki, I. J. Munjeri, and N. U.
Putri, "A water flow algorithm based optimization model for road traffic engineering," in 2016 International Conference on Advanced Computer Science and Information Systems, ICACSIS 2016, 2017, pp. 591-596.

[16] S. Zainudin, M. M. Kerwad, and Z. A. Othman, "A water flow-like algorithm for capacitated vehicle routing problem," J. Theor. Appl. Inf. Technol., vol. 77, no. 1, pp. 125-135, 2015.

[17] A. Srour, Z. A. Othman, and A. R. Hamdan, "A Water Flow-Like Algorithm for the Travelling Salesman Problem,” Adv. Comput. Eng., vol. 2014, pp. 1-14, 2014.

https://doi.org/10.1155/2014/436312

[18] A. A. Soebroto, I. Cholissodin, R. C. Wihandika, M. T. Frestantiya, and Z. El Arief, "Prediksi Tinggi Muka Air (TMA) Untuk Deteksi Dini Bencana Banjir Menggunakan SVR-TVIWPSO,” J. Teknol. Inf. dan Ilmu Komput., vol. 2, no. 2, p. 79, 2015.

[19] J. Sunkpho and C. Ootamakorn, "Real-time flood monitoring and warning system," Songklanakarin J. Sci. Technol., vol. 33, no. 2, pp. 227-235, 2011.

[20] D. W. Sasmojo, W. Broto, and A. Saputra, "BANJIR," Sist. Pakar pada Sist. Inf. Peringatan Dini Banjir, pp. 65-70, 2015.

[21] C. Umari, E. Anggraini, and Zainul Muttaqinm Rofif, "Rancang Bangun Sistem Peringatan Dini Banjir Berbasis Sensor Ultrasonik Dan Mikrokontroler Sebagai Upaya Penanggulangan Banjir,” J. Meteorol. Klimatologi dan Geofis., vol. 4, no. 2, pp. 35-42, 2017.

[22] T. H. Wu, S. H. Chung, and C. C. Chang, "A water flow-like algorithm for manufacturing cell formation problems," Eur. J. Oper. Res., vol. 205, no. 2, pp. 346-360, 2010.

https://doi.org/10.1016/j.ejor.2010.01.020

[23] C. Chang and T. Wu, "A water flow-like algorithm for cellular manufacturing design and layout," 2011.

[24] Y. H. Teng, K. K. Kuok, M. Imteaz, W. Y. Lai, and K. X. Ling, International Journal of Advanced Trends in Computer Science and Engineering Available Online at

http://www.warse.org/IJATCSE/static/pdf/file/ijatcse 04832019.pdf Development of "Whale Optimization Neural Network for Daily Water Level Forecasting," vol. 8, no. 3, pp. 354-362, 2019. https://doi.org/10.30534/ijatcse/2019/04832019

[25] G. Booch, R. A. Maksimchuk, M. W. Engle, B. J. Young, J. Connallen, and K. A. Houston, Object-oriented analysis and design with applications, third edition, vol. 33, no. 5. 2008. https://doi.org/10.1145/1402521.1413138

[26] D. E. Dougherty and R. A. Marryott, "Optimal Groundwater Management: 1. Simulated Annealing," Water Resour. Res., vol. 27, no. 10, 1991. 
[27] V. Te Chow, Hidrolika Saluran Terbuka, 2nd ed. Jakarta: Jakarta : Penerbit Erlangga, 1984.

[28] Dinas Sumber Daya Air, "Data pengukuran melintang kali Ciliwung," Bidang Pengendali Banjir dan Drainase, Jakarta, 2020.

[29] Z. Xiao, Z. Liang, B. Li, B. Hou, Y. Hu, and J. Wang, "New Flood Early Warning and Forecasting Method Based on Similarity Theory," J. Hydrol. Eng., vol. 24, no. 8, 2019.

[30] S. Oktafiani and D. N. Utama, "International Journal of Advanced Trends in Computer Science and Engineering (IJATCSE) - Generic model of fuzzy profile matching for determining the best marketer," Int. J. Adv. Trends Comput. Sci. Eng., vol. 9, no. 1, pp. 859-869, 2020.

https://doi.org/10.30534/ijatcse/2020/123912020

[31] D. N. Utama, F. A. Zaki, I. J. Munjeri, and N. U. Putri, "FWFA Optimization based Decision Support System for Road Traffic Engineering," 2016.

https://doi.org/10.1088/1742-6596/801/1/012016 